\title{
Physical and physiological quality of seeds of Campo Grande Stylosanthes coated with different binder materials
}

\author{
Danilo Força Baroni ${ }^{1^{*}(\mathbb{D})}$ Henrique Duarte Vieira ${ }^{1}$ Flávio Wirlan Andrade da Silva ${ }^{1}$ (D) \\ Amanda Justino Acha1 ${ }^{1}$ José Inácio Coelho Pires ${ }^{1}(\mathbb{D})$
}

${ }^{1}$ Programa de Pós-graduação em Produção Vegetal, Universidade Estadual do Norte Fluminense Darcy Ribeiro (UENF), 28016-811, Campos dos Goytacazes, RJ, Brasil. E-mail: baronidf@gmail.com. "Corresponding author. ABSTRACT: The binder materials used in seed coating provide adherence of the filler materials onto the seeds. Adequate concentrations
of the binder promote good physical characteristics of coating while not impairing seed physiological characteristics. Thus, the objective of
this study was to evaluate the type and the concentration of binder materials that allow the best physical and physiological characteristics in
coated seeds of Campo Grande Stylosanthes. Seed coating was carried out in a coating pan, using sand as the filling material. The treatments
consisted of 2 types of binders mixed in 3 ratios (PVA glue and gum arabic glue, diluted in water, 3:1, 2:1, and 1:1), and uncoated seeds as
control. The coated seeds were evaluated for physical and physiological characteristics. The laboratory and greenhouse experiments were
arranged in a completely randomized design. Results showed that at the different concentrations used this study, neither the PVA glue nor
the gum arabic glue had any effect on the physiological quality of Campo Grande Stylosanthes seeds. However, PVA glue in the ratio of $2: 1$
provided the greatest surface area, maximum diameter, minimum diameter, and sphericity to coated seeds.

Key words: germination, coating, Stylosanthes capitata/macrocephala.

Qualidade física e fisiológica de sementes de Stylosanthes Campo Grande revestidas com diferentes materiais cimentantes

RESUMO: No processo de revestimento, os materiais cimentantes são os responsáveis por conferir a adesão dos materiais de enchimento às sementes. Concentrações adequadas de material cimentante promovem revestimento com boas características fisicas e que não prejudiquem as características fisiológicas das sementes. Assim, o objetivo desse trabalho foi verificar o tipo e a concentração de material cimentante que possibilite as melhores características físicas e fisiológicas em sementes revestidas de estilosantes Campo Grande. O revestimento foi realizado em drageadora, utilizando areia como material de enchimento. Os tratamentos foram compostos por 2 tipos de materiais cimentantes em 3 proporções (cola cascorez extra e cola goma arábica, diluídas em água, 3:1, 2:1 e 1:1), além das sementes não revestidas, como controle. Após o revestimento, as sementes foram avaliadas quanto às características físicas e fisiológicas. O delineamento adotado foi inteiramente casualizado em laboratório e em casa de vegetação. Verificou-se que as colas cascorez extra e goma arábica não interferiram na qualidade fisiológica das sementes de estilosantes Campo Grande nas diferentes concentrações utilizadas. Entretanto, a cola cascorez extra na proporção 2:1 proporcionou maior área, diâmetro máximo, diâmetro mínimo e esfericidade nas sementes revestidas.

Palavras-chave: germinação, revestimento, Stylosanthes capitata/macrocephala.

\section{INTRODUCTION}

Cattle has been raised in Brazil mainly in extensive pasture systems. However, approximately $60 \%$ of these areas with cultivated pasture are in an advanced state of degradation (BARDUCCI et al., 2009). The main causes of this problem are related to unsuitable management of pastures and animals (LIMA et al., 2011).

One of the main factors related to pasture degradation is the inadequate replenishment of nutrients in the soil. Thus, the use of fabaceae species in these pasture systems is considered a strategy to minimize these problems (BARCELLOS et al., 2008). Among fabaceae species, Campo Grande
Stylosanthes provides important advantages. The Stylosanthes spp. is mainly used for soil improvement and improving natural grassland (CHANDRA, 2009).

Therefore, strategies and techniques are fundamental to enable the establishment of these plants in the field, since this is the period of greatest susceptibility to external factors. The use of good quality seeds is one of the strategies that must be adopted. Techniques such as coating have been widely used because of the benefits to seeds. Benefits of coating include the change in size and shape of seeds, the possibility of incorporating nutrients, growth regulators, insecticides, and fungicides (ACHA et al., 2016).

Despite these advantages, the methods for coating application are not disclosed, as they are 
treated as trade secret (FUNGUETTO, 2007). Thus, studies have been developed to clarify basic aspects of the coating process such as types of fillers and binders, methods of application, types of nutrients, and adequate doses (MENDONÇA et al., 2007; XAVIER et al., 2015; ACHA et al., 2016).

For a good coating, it is essential to find the ideal ratios between fillers and binders. However, few researchers have addressed the question of the effect of binders and their ratios on seeds. Binders provide adherence of fillers onto the seed. However, this characteristic is determined as a function of the concentration used, and in excess, it can result in high resistance to water imbibition by the seed, but in scarcity, it provides little or no adherence of the filler materials.

Several authors have used PVA glue as binder material (PEREIRA et al., 2011; XAVIER et al., 2015; ACHA et al., 2016). However, few studies have addressed the ideal ratio of this material in the coating, which is limited to the research of MENDONÇA et al. (2007).

In this context, the objective of this research was to analyze the type and the concentration of binder materials that allow the best physical and physiological characteristics in coated seeds of Campo Grande Stylosanthes.

\section{MATERIALS AND METHODS}

Commercial seeds of Campo Grande Stylosanthes, with $96.1 \%$ purity and $61 \%$ germination, 2014/2015 harvest, were used in the experiment.

Before starting the coating process, the seeds were subjected to mechanical scarification using 100-grit sandpaper to break the integumentary dormancy. The seeds were initially divided into $100-\mathrm{g}$ portions, corresponding to the replicates. In order to standardize the process, seeds in each repetition were manually scarified for ten minutes.

Sand was used as a filler for the seed coating. The sand was previously sieved through a $0.250 \mathrm{~mm}$ screen opening, washed in tap water to complete removal of contaminants, and dried in a forced ventilation oven for 24 hours at $105^{\circ} \mathrm{C}$.

As binder materials, Henkel ${ }^{\circledR}$ PVA-based glue and Radex ${ }^{\circledR}$ gum arabic glue were used in three ratios $(3: 1 ; 2: 1$; and $1: 1$ of water to glue), diluted in heated water at $70{ }^{\circ} \mathrm{C}, 12$ hours before starting the coating process. Eight seed-coating treatments were tested: NSC: Non-scarified control (intact seeds without coating); SCC: Scarified control (scarified seeds without coating); PG 3:1= PVA glue (PG)
3:1 ratio, water:glue; PG 2:1= PVA glue (PG) 2:1 ratio, water:glue; PG 1:1= PVA glue $(\mathrm{PG})$ 1:1 ratio, water:glue; GA 3:1= gum arabic glue (GA) ratio 3:1, water:glue; GA 2:1= gum arabic glue (GA) ratio 2:1 ratio, water:glue; GA 1:1= gum arabic glue (GA) ratio $1: 1$, water:glue.

The following equipment was used: a stainless steel N10 Newpack ${ }^{\circledR}$ coating pan with a tank; compressed air spray gun to apply the binder solution; hot air blower; timer to set the blower operating time. The coating consisted of 12 layers of the filler, each layer containing 25 grams (g) of filler, applied in two portions of $12.5 \mathrm{~g}$.

The seeds were placed into the coating pan and the filler material was added. The pan was set at $77 \mathrm{rpm}$ and the binder solution was pumped at a pressure of 4 bar. After each portion of the filler was added, the binder solution was sprayed onto the moving seed mass, for three seconds. After adding the second portion of the filler, the hot air blower was operated at $50{ }^{\circ} \mathrm{C}$. This protocol refers to the procedure of coating one layer, thus it was repeated 12 times for the complete coating. The duration of hot air application varied according to the treatments as to ensure the best drying of the coated seeds. In the treatments PG 3:1 and 2:1, the hot air blower operated 180 seconds at $50{ }^{\circ} \mathrm{C}$ for the first two layers and 90 seconds for the other layers of the coating; in PG 1:1, the hot air blower operated for 90 seconds at $50^{\circ} \mathrm{C}$ for each coating layer, from the first to the last layer; in GA 3:1, 2:1, and 1:1: the hot air blower operated for 240 seconds at $50{ }^{\circ} \mathrm{C}$ on the first two layers and 120 seconds on the other layers of the coating. This was necessary because of the water to glue ratios in the treatments.

The analyses of electrical conductivity and $\mathrm{pH}$ of the binder materials were carried out. For both tests, four replicates with $50 \mathrm{~mL}$ were prepared for each treatment. Physical and physiological characteristics of the coated seeds were assessed as described below.

To evaluate the physiological characteristics, germination test and germination rate (GR) were performed in the laboratory, and emergence test and emergence speed index (ESI) were performed in the greenhouse, following the recommendations of the Rules for Seed Testing (Brasil 2009). In the greenhouse, plants were irrigated twice a day (morning and afternoon), to keep the substrate (sand washed: soil, in the ratio 2:1) always moist. The formula proposed by MAGUIRE (1962) was used to calculate GR and ESI.

Biometric analyses of shoot and roots (BM) and dry mass (g. plant $\left.{ }^{-1}\right)$ of shoot (DMS) and 
root (DMR) were determined. Length of shoot (SL) and root system $(\mathrm{RL})$ was measured with a millimeter ruler. Ten random plants were selected from each replicate for the measurement. These biometric analyses were performed in seedlings grown in the greenhouse.

The DMS and DMR were determined in the seedlings used for the biometric test. Subsequently, each material was packed in paper bags and taken to a forced ventilation oven with at $65^{\circ} \mathrm{C}$, for 72 hours. After drying and cooling the material in a desiccator, the repetitions were weighed in a $0.0001 \mathrm{~g}$ analytical balance.

The physical characteristics evaluated included: thousand seed weight (TSW), \% of multiple seeds (MS), and seed biometry. TSW was performed according to the recommendations of the Rules for Seed Testing (BRASIL, 2009). The MS percentage was determined using a $3 \mathrm{~mm}$ mesh sieve to separate units coated with more than one seed. Seeds were placed on the sieve and the sieve was shaken with circular motions for at least 30 seconds. Seed biometry was determined in the Seed Analysis System (Groundeye ${ }^{\circledR}$ ) using four replicates of 50 seeds for each treatment. The variables studied were seed surface area (SA), maximum diameter (MXD), minimum diameter (MID), circularity (CIR).

The laboratory and greenhouse experiments were arranged in a completely randomized design with eight treatments and four replicates with 50 seeds each, totaling 32 experimental units. Lilliefors, Cochran, and Bartlett tests used to verify normality and homogeneity of variances indicated the need for the arcsine square root transformation (or angular transformation) for percentage data of the variables germination and emergence. The other variables described were transformed by the square root of the function ( $\mathrm{x}$ $+1)$. Data were analyzed by analysis of variance $(\mathrm{p} \leq 0.05)$ and mean comparison Tukey test $(\mathrm{p} \leq 0.05)$.

The results were presented with untransformed means. The software program used to analyze the data was SAEG 9.1 (UFV, 2007).

\section{RESULTS AND DISCUSSION}

The analysis of variance showed no significant difference $(\mathrm{P} \leq 0.05)$ for percentage of germination $(\mathrm{G})$, emergence (E) and emergence speed index (ESI). Conversely, significant difference $(\mathrm{P} \leq 0.05)$ was reported for percentage of hard seeds (HS), abnormal seedlings (AS) and germination speed index (GSI) (Table 1). The results confirmed $6 \%$ of $\mathrm{HS}$, in other words, with integumentary dormancy in the treatment of non-scarified seeds (NSC). However, this result was not enough to interfere in the $\mathrm{G}, \mathrm{E}$, and GSI and ESI, since both non-scarified (NSC) and scarified (SCC) seeds showed no significant difference for these variables.

The percentage of abnormal seedlings (AS) (Table 1) was low in all evaluated treatments, with significant difference $(\mathrm{P} \leq 0.05)$ only between the

Table 1 - Germination percentage (G), hard seed (HS), abnormal seedlings (AS), and germination speed index (GSI) in laboratory and emergence percentage (E) and emergence speed index (ESI) in greenhouse at 30 days of Campo Grande Stylosanthes seeds coated with different binders in different concentrations.

\begin{tabular}{|c|c|c|c|c|c|c|}
\hline TREAT. & $\mathrm{G}(\%)^{\mathrm{ns}}$ & HS (\%) & AS (\%) & GSI & $\mathrm{E}(\%)^{\mathrm{ns}}$ & $\mathrm{ESI}^{\mathrm{ns}}$ \\
\hline NSC & 65.50 & $6.00 \mathrm{a}$ & $0.00 \mathrm{~b}$ & $9.57 \mathrm{ab}$ & 37.00 & 3.28 \\
\hline $\mathrm{SCC}$ & 74.00 & $0.50 \mathrm{~b}$ & $1.50 \mathrm{ab}$ & $12.01 \mathrm{a}$ & 32.50 & 3.15 \\
\hline PG 3:1 & 69.50 & $1.00 \mathrm{~b}$ & $2.00 \mathrm{ab}$ & $11.17 \mathrm{ab}$ & 38.00 & 3.94 \\
\hline PG 2:1 & 67.00 & $0.50 \mathrm{~b}$ & $2.50 \mathrm{ab}$ & $10.98 \mathrm{ab}$ & 45.00 & 4.14 \\
\hline PG 1:1 & 65.50 & $0.00 \mathrm{~b}$ & $3.00 \mathrm{ab}$ & $10.46 \mathrm{ab}$ & 43.00 & 4.25 \\
\hline GA $3: 1$ & 61.00 & $0.00 \mathrm{~b}$ & $4.50 \mathrm{ab}$ & $9.11 \mathrm{~b}$ & 22.00 & 2.13 \\
\hline GA $2: 1$ & 62.00 & $0.00 \mathrm{~b}$ & $3.50 \mathrm{ab}$ & $9.17 \mathrm{~b}$ & 31.50 & 3.03 \\
\hline GA $1: 1$ & 67.00 & $0.00 \mathrm{~b}$ & $6.00 \mathrm{a}$ & $10.33 \mathrm{ab}$ & 27.00 & 2.48 \\
\hline LSD & - & 3.37 & 5.23 & 2.62 & - & - \\
\hline CV (\%) & 10.59 & 125.57 & 67.06 & 10.85 & 19.77 & 15.19 \\
\hline
\end{tabular}

${ }^{(n s)}$ Non-significant by $\mathrm{F}$ test $(\mathrm{p} \leq 0.05)$. Means followed by the same letter are not significantly different by the Tukey test ( $\left.\mathrm{p} \leq 0.05\right)$. NSC: Non-scarified control (intact seeds without coating); SCC: Scarified control (scarified seeds without coating); PG 3:1= PVA glue (PG) 3:1 ratio, water:glue; $P G$ 2:1= PVA glue (PG) 2:1 ratio, water:glue; PG 1:1= PVA glue (PG) 1:1 ratio, water:glue; GA 3:1= gum arabic glue (GA) 3:1 ratio, water:glue; GA 2:1= gum arabic glue (GA) 2:1 ratio, water:glue; GA 1:1= gum arabic glue (GA) 1:1 ratio, water:glue. 
non-scarified control (NSC) and the treatment GA 1:1 (gum arabic in 1:1 water to glue ratio). It is likely that the physical barrier imposed by the coating has contributed to the difference between the treatments. Despite the small difference, the increase of abnormal plants indicated the difficulty of the coated seeds in producing normal plants.

The increase in AS possibly occurred due to the high concentration of gum arabic in the binder solution, which resulted in high adhesion of the filler to the seed. The GA 1:1 coating may have also made it more difficult for water to enter the seed during the imbibition process, delaying the different germination phases and favoring an increase in the formation of abnormal seedlings.

SANTOS et al. (2010) also evaluated the effect of different coating materials on seeds of Brachiaria brizantha $\mathrm{cv}$. Marandu. They reported that seeds coated with sand + PVA (polyvinyl acetate) and sand $+\mathrm{CaSiO} 3+\mathrm{PVA}$ or polymer, chemically treated (Carbendazim + Thiram and Fipronil), maintained their physiological quality over 12 months of storage, while coating with betonite and/or limestone impaired the physiological quality of the seeds stored.

As table 1 shows, there is a significant reduction of GSI in relation to the scarified control (SCC) only for the treatments GA 3:1 and 2:1. According to SANTOS et al. (2010), the coating is a physical barrier for root protrusion, delaying germination.

Thus, the results indicated that the coated seeds were capable of overcoming this barrier and establishing normal seedlings, as observed by SILVA et al. (2017). It also showed that the coating formed allowed good aeration and low resistance after imbibition, allowing water to enter the seed, and consequently, the good development of seedling.

Conversey, the $\mathrm{pH}$ of the binder materials and the electrical conductivity (Table 2) may have influenced the rate of germination of the treatments with gum arabic.
A higher concentration of salts has been reported in gum arabic than in PVA glue. BARRETO et al. (2010) argued that the salinity of the substrate or water used in irrigation stands out as one of the limiting factors affecting seed germination.

With the variables G, E, and GSI, it was possible to reaffirm that the binder materials associated with the different ratios used did not interfere in the physiological quality of the seeds of Campo Grande Stylosanthes.

SILVA et al. (2017) also reported that emergence and emergence speed index of Campo Grande Stylosanthes seeds were not impaired by the coating, using 1:1 PVA glue as binder.

It is apparent from table 3 that there was no significant difference between the treatments for the variables length of shoot (SL), length of root (RL), and dry mass of roots (DMR). However, the treatment PG 2:1 (PVA glue 2:1 ratio) showed mean of dry mass of shoot (DMS) higher than GA 3:1 (gum arabic 3:1 ratio) and non-significantly different from the others.

The treatment GA 3:1 had the lowest GSI, when compared with the scarified control (SCC), but showed no significant difference $(\mathrm{P} \leq 0.05)$ for germination percentage.

This finding indicates that treatment GA 3:1 impaired seed vigor, but not enough to affect the formation of normal seedlings. However, less vigorous plants were formed, with lower capacity for growth and development, which contributed to the lower shoot dry mass (DMS). HENNING et al. (2010) observed that vigorous seeds produced seedlings with higher dry mass compared with less vigorous seeds.

We observed from tables 1 and 3 , which showed the variables related to physiological characteristics, both in laboratory and in greenhouse, and growth characteristics in greenhouse, that in general the types and concentrations of the binders had no effect on the physiological quality of the seeds, as there was no significant difference $(\mathrm{P} \leq 0.05)$ in

Table 2 - $\mathrm{pH}$ values and electrical conductivity of the binder materials used in the different ratios.

\begin{tabular}{|c|c|c|c|}
\hline \multirow[t]{2}{*}{ Binder material (BM) } & \multicolumn{3}{|c|}{ 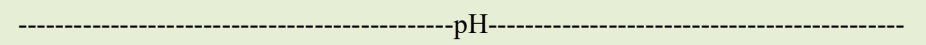 } \\
\hline & $3: 1$ & $2: 1$ & $1: 1$ \\
\hline PVA glue & 3.93 & 3.95 & 3.94 \\
\hline Gum arabic & 8.82 & 8.85 & 8.88 \\
\hline \multicolumn{4}{|c|}{ 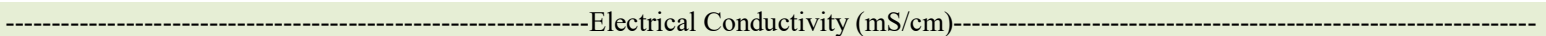 } \\
\hline PVA glue & 0.87 & 1.03 & 1.33 \\
\hline Gum arabic & 2.95 & 3.06 & 4.15 \\
\hline
\end{tabular}


Table 3 - Shoot length (SL), root length (RL), shoot dry mass (DMS), and root dry mass (DMR) of Campo Grande Stylosanthes seedlings in greenhouse, 30 days after sowing.

\begin{tabular}{lcccc}
\hline TREAT. & SL $(\mathrm{cm})^{\mathrm{ns}}$ & RL $(\mathrm{cm})^{\mathrm{ns}}$ & DMS $\left(\mathrm{mg}^{\left.\mathrm{p} l^{-1}\right)}\right.$ & DMR $\left(\mathrm{mg} \cdot \mathrm{pl}^{-1}\right)^{\mathrm{ns}}$ \\
\hline NSC & 2.20 & 11.65 & $9.75 \mathrm{ab}$ & 2.80 \\
SCC & 2.10 & 13.56 & $8.30 \mathrm{ab}$ & 2.50 \\
PG 3:1 & 2.14 & 12.23 & $9.85 \mathrm{ab}$ & 2.95 \\
PG 2:1 & 2.26 & 14.09 & $11.22 \mathrm{a}$ & 3.47 \\
PG 1:1 & 2.09 & 10.45 & $9.62 \mathrm{ab}$ & 2.30 \\
GA 3:1 & 1.97 & 11.68 & $6.10 \mathrm{bq}$ & 1.82 \\
GA 2:1 & 2.13 & 13.19 & $9.67 \mathrm{ab}$ & 3.02 \\
GA 1:1 & 2.08 & 13.00 & $8.45 \mathrm{ab}$ & 2.40 \\
LSD & - & - & 3.9 & - \\
CV $(\%)$ & 6.89 & 18.4 & 18.33 & 29.46 \\
\hline
\end{tabular}

(ns) Non significant by the $\mathrm{F}$ test $(\mathrm{p} \leq 0.05)$. Means followed by the same letter are not significantly different by the Tukey test ( $\mathrm{p} \leq 0.05$ ). NSC: Non-scarified control (intact seeds without coating); SCC: Scarified control (scarified seeds without coating); PG 3:1= PVA glue (PG) 3:1 ratio, water:glue; PG 2:1= PVA glue (PG) 2:1 ratio, water:glue; PG 1:1= PVA glue (PG) 1:1 ratio, water:glue; GA 3:1= gum arabic glue (GA) 3:1 ratio, water:glue; GA 2:1= gum arabic glue (GA) 2:1 ratio, water:glue; GA 1:1= gum arabic glue (GA) 1:1 ratio, water:glue.

relation to the controls. This is an extremely positive result, since several studies (SANTOS et al., 2010; PEREIRA et al., 2011) have reported impairment of physiological characteristics of seeds due to coating. Therefore, it is possible to include in the coating formulation components that will add value to seeds such as insecticides, fungicides, growth regulators, and nutrients.
Because the treatments had no effect on the physiological quality of the seeds, it was possible, with the physical variables from table 4 , to define the treatment that provided the best seed coat quality. There was significant difference $(\mathrm{P} \leq 0.05)$ between the treatment means for the variables, surface area, maximum diameter, minimum diameter, circularity, and sphericity of the seeds.

Table 4 - Surface area (SA), maximum diameter (MXD), minimum diameter (MID), circularity (CIR), and sphericity (SP) of Campo Grande Stylosanthes seeds coated with different binders in different concentrations in laboratory.

\begin{tabular}{|c|c|c|c|c|c|}
\hline TREAT. & $\mathrm{SA}\left(\mathrm{mm}^{2}\right)$ & $\mathrm{MXD}(\mathrm{mm})$ & $\mathrm{MID}(\mathrm{mm})$ & CIR & SP \\
\hline NSC & $2.47 \mathrm{c}$ & $2.28 \mathrm{~d}$ & $1.36 \mathrm{c}$ & $0.61 \mathrm{c}$ & $16.34 \mathrm{a}$ \\
\hline SCC & $2.57 \mathrm{c}$ & $2.29 \mathrm{~d}$ & $1.38 \mathrm{c}$ & $0.61 \mathrm{c}$ & $16.31 \mathrm{a}$ \\
\hline PG 3:1 & $3.74 \mathrm{ab}$ & $2.64 \mathrm{ab}$ & $1.73 \mathrm{~b}$ & $0.68 \mathrm{~b}$ & $15.93 \mathrm{bc}$ \\
\hline PG 2:1 & $4.20 \mathrm{a}$ & $2.76 \mathrm{a}$ & $1.87 \mathrm{a}$ & $0.70 \mathrm{ab}$ & $15.74 \mathrm{c}$ \\
\hline PG 1:1 & $3.73 \mathrm{~b}$ & $2.58 \mathrm{bc}$ & $1.77 \mathrm{ab}$ & $0.70 \mathrm{ab}$ & $15.81 \mathrm{c}$ \\
\hline GA $3: 1$ & $3.37 \mathrm{~b}$ & $2.48 \mathrm{c}$ & $1.67 \mathrm{~b}$ & $0.70 \mathrm{ab}$ & $15.63 \mathrm{c}$ \\
\hline GA $2: 1$ & $3.67 \mathrm{~b}$ & $2.55 \mathrm{bc}$ & $1.75 \mathrm{ab}$ & $0.72 \mathrm{a}$ & $15.90 \mathrm{bc}$ \\
\hline GA 1:1 & $3.83 \mathrm{ab}$ & $2.61 \mathrm{bc}$ & $1.78 \mathrm{ab}$ & $0.72 \mathrm{a}$ & $16.18 \mathrm{ab}$ \\
\hline LSD & 0.05 & 0.13 & 0.12 & 0.03 & 0.36 \\
\hline CV (\%) & 1.97 & 2.32 & 3.29 & 0.56 & 1.00 \\
\hline
\end{tabular}

Means followed by the same letter are not significantly different by the Tukey test $(\mathrm{p} \leq 0.05)$. NSC: Non-scarified control (intact seeds without coating); SCC: Scarified control (scarified seeds without coating); PG 3:1= PVA glue (PG) 3:1 ratio, water:glue; PG 2:1= PVA glue (PG) 2:1 ratio, water:glue; PG 1:1= PVA glue (PG) 1:1 ratio, water:glue; GA 3:1= gum arabic glue (GA) 3:1 ratio, water:glue; GA 2:1= gum arabic glue (GA) 2:1 ratio, water:glue; GA 1:1= gum arabic glue (GA) 1:1 ratio, water:glue. 
The variable surface area showed us how much the seed increased in size, when subjected to the coating treatments. It is possible to see from table 4 that all treatments receiving coating had seeds with area significantly $(\mathrm{p} \leq 0.05)$ greater than the controls (NSC and SCC).

The treatment PG 2:1 was superior to the others in relation to the seed area, although, it was not significantly different from PG 3:1 and GA 1:1, indicating that PG 2:1 provided a seed surface area that was not surpassed by any other treatment. PG 2:1 also presented the highest values for MXD and MID, although it was not significantly different from PG 3:1 for maximum diameter or from PG 1:1, GA 2:1, and GA 1:1 for minimum diameter. Results also showed that the control treatments had the lowest values for these variables. Increase in MXD and MID improved seed distribution in the sowing row at planting time.

The variable circularity is a measure of the roundness of an object, the value equals to 1 for a circular object and less than 1 for an object that departs from the circular shape. Thus, table 4 shows that the coating, regardless of the type and concentration of the binder, made the seeds more circular, because all treatments differed statistically $(\mathrm{P} \leq 0.05)$ from the controls (NSC and SCC). In addition, treatments GA 2:1 and GA 1:1 differed statistically from PG 3:1, showing greater circularity.

According to NASCIMENTO et al. (2009), coating modify seed into a more rounded shape and increases its size, allowing better distribution at sowing, manual or mechanical sowing. We noted from table 4 that besides the coating increase the size of the seed, the maximum and minimum diameters, it also provided them with a more rounded shape. This demonstrated that the coating adhered to the seed uniformly and allowed a good finishing.

These changes in the physical characteristics of the seeds are fundamental for sowing, because color, size, and shape facilitate distribution and identification in the planting furrow and help to avoid thinning in some crops species (SILVA et al., 2017).

There was significant difference $(\mathrm{P} \leq 0.05)$ for the variables percentage of multiple seeds and thousand seed weight (TSW) (Table 5). The treatment GA 1:1 showed the highest percentage of multiple seeds, although, it was not significantly different $(\mathrm{P} \leq 0.05)$ from treatments $1: 1, \mathrm{GA} 3: 1$, and GA 2:1.

Multiple seeds are usually formed due to the high concentration of glue in the binder solution, which considerably increases its adhesive power. The high adhesive power hinders the motion of the seeds inside the rotating pan, and then they will adhere to each other.

Data from table 5 confirmed that the coating enabled seeds to increase their weight from 2.5 to 3.6 times. MENDONÇA et al. (2007) also reported that the coating has more than doubled the weight of super sweet corn seeds. Thus, GA 1:1, PG 2:1, and GA 2:1 treatments showed the highest TSW, although, GA 2:1 and PG 2:1 were not significantly different from PG 1:1 and GA 3:1.

Table 5 - Multiple seeds (MS) and thousand seed weight (TSW) of seeds of Campo Grande Stylosanthes coated with different binder materials in different concentrations evaluated in laboratory.

\begin{tabular}{lcc}
\hline TREAT. & MS (\%) & TSW (g) \\
\hline NSC & - & $2.26 \mathrm{~d}$ \\
SCC & - & $2.31 \mathrm{~d}$ \\
PG 3:1 & $0.24 \mathrm{~b}$ & $4.80 \mathrm{c}$ \\
PG 2:1 & $0.28 \mathrm{~b}$ & $5.68 \mathrm{ab}$ \\
PG $1: 1$ & $0.58 \mathrm{ab}$ & $5.33 \mathrm{bc}$ \\
GA $3: 1$ & $0.48 \mathrm{ab}$ & $5.15 \mathrm{bc}$ \\
GA 2:1 & $0.38 \mathrm{ab}$ & $5.74 \mathrm{ab}$ \\
GA 1:1 & $0.88 \mathrm{a}$ & $5.95 \mathrm{a}$ \\
LSD & 0.59 & 0.6 \\
CV $(\%)$ & 34.11 & 8.02 \\
\hline
\end{tabular}

Means followed by the same letter are not significantly different by the Tukey test $(\mathrm{p} \leq 0.05)$. NSC: Non-scarified control (intact seeds without coating); SCC: Scarified control (scarified seeds without coating); PG 3:1= PVA glue (PG) 3:1 ratio, water:glue; PG 2:1= PVA glue (PG) 2:1 ratio, water:glue; PG 1:1= PVA glue (PG) 1:1 ratio, water:glue; GA 3:1= gum arabic glue (GA) 3:1 ratio, water:glue; GA 2:1= gum arabic glue (GA) 2:1 ratio, water:glue; GA 1:1= gum arabic glue (GA) 1:1 ratio, water:glue. 
Comparing the treatments for multiple seeds and thousand seed weight showed that GA 1:1 had the highest values of MS and TSW, while PG 2:1 allowed TSW significantly equal to GA $1: 1$ and the lowest values of multiple seeds. This indicated the efficiency of the coating method, meaning that the ratio of the binder material, the ratio of the filler material, the drying time, and the number of layers used in the coating process were optimal, as it allowed increase in seed weight and low formation of multiple seeds.

By analyzing the data in tables 4 and 5, one can see that the treatment PG 2:1 provided the best coating to the seeds. PG $2: 1$, in addition to not interfering in the physiological quality of the seeds, was placed among the best results for all physical characteristics evaluated, which has not happen with the other treatments.

Several authors (XAVIER et al., 2015; SILVA et al., 2017) have worked with the binder solution in the 1:1 water to PVA glue ratio, assuming that it is the ideal coating for the seeds. However, in this study, we reported that the 2:1 water to PVA glue ratio provided the best physical characteristics to the coated seeds when compared with the 1:1 adhesive solution. This finding allowed us to reduce the amount of glue in the binder solution without damaging the physical and physiological characteristics of the seeds.

\section{CONCLUSION}

- PVA glue and gum arabic in the different concentrations used in this study showed no interference in the physiological quality of seeds of Campo Grande Stylosanthes;

- The binder solution in the 2:1 water to PVA glue ratio provided the best physical characteristics to the coating of Campo Grande Stylosanthes seeds.

\section{ACKNOWLEDGMENTS}

This study was funded by the Coordenação de Aperfeiçoamento de Pessoal de Nível Superior (CAPES - Finance code 001) and Fundação de Amparo à Pesquisa do Estado do Rio de Janeiro - FAPERJ. The author DFB thanks CAPES for granting the scholarship and State University of North Fluminense (UENF) for learning opportunity.

\section{DECLARATION OF CONFLICT OF INTEREST}

The authors declared no potential conflicts of interest with respect to the research, authorship, and/or publication of this article.

\section{AUTHORS' CONTRIBUTIONS}

All authors contributed equally for the conception and writing of the manuscript. All authors critically revised the manuscript and approved of the final version.

\section{REFERENCES}

ACHA, A. J. et al. Perennial soybean seeds coated with high doses of boron and zinc. African Journal of Biotechnology, v.15, n.37, p.1998-2005, 2016. Available from: <https://www.ajol.info/index. php/ajb/article/view/144449>. Accessed: Jan. 19, 2018.

BARCELLOS, A. O. et al. Sustainability of animal production based in intercropped pasture and in the use of exclusive legumes, in protein bank forms, in the brazilian tropics. Revista Brasileira de Zootecnia, v.37, n.SPE, p.51-67, 2008. Available from: <http://www.scielo.br/scielo. php? pid $=$ S1516-35982008001300008\&script $=$ sci_arttext $>$. Accessed: Feb. 02, 2018.

BARDUCCI, R. S. et al. Yield of Brachiaria brizantha and Panicum maximum with corn and nitrogen fertilization.. Archivos de zootecnia, v.58, n.222, p.211-222, 2009. Available from: $\quad<$ http://scielo.isciii.es/scielo.php?script=sci_arttext\&pid $=$ S0004-05922009000200006 $>$. Accessed: Jan. 20, 2018

BARRETO, H. B. F. et al. Effect of salin water irrigation in the germination of sábia seeds (Mimosa caesalpiniifolia Benth). Revista Verde de Agroecologia e Desenvolvimento Sustentável, v.5, n.3, p.125-130, 2010. Available from: <https://www.gvaa. com.br/revista/index.php/RVADS/article/viewFile/314/314>. Accessed: Jun. 10, 2018.

BRASIL. Rules to seed testing. Ministério da agricultura, pecuária e abastecimento, p. 395, 2009. Available from: <http://www. agricultura.gov.br/assuntos/insumos-agropecuarios/arquivospublicacoes-insumos/2946 regras analise sementes.pdf $>$. Accessed: Feb. 02, 2020.

CHANDRA, A. Diversity among Stylosanthes species: Habitat, edaphic and agro-climatic affinities leading to cultivar development. Journal of Environmental Biology. 2009, 30, 471478. Available from: $<$ https://pubmed.ncbi.nlm.nih.gov/20120482diversity-among-stylosanthes-species-habitat-edaphic-and-agroclimatic-affinities-leading-to-cultivar-development $>$. Accessed: Feb. 02, 2020.

FUNGUETTO, C. I. Seed treatment for large croops with micronutrient zinc, fungicides and polymers.. Norte Científico, v.2, n.1, p.64-72, 2007. Available from: <http://www.repositorio. ufpel.edu.br/bitstream/123456789/1436/1/tese_claudete funguetto.pdf $>$. Accessed: Feb. 02, 2020.

HENNING, F. A. et al. Chemical composition and mobilization of content in soybean seeds of high and low vigor. Bragantia, v.69, n.3, p.727-734, 2010. Available from: <https://www.redalyc.org/ html/908/90816059026/>. Accessed: Jan. 11, 2018.

LIMA, S. S. et al. Relation between termite mounds and pasture degradation. Pesquisa Agropecuária Brasileira, v.46, n. 12, p.16991706, 2011. Available from: <https:/www.alice.cnptia.embrapa br/bitstream/doc/917333/1/Relacaoentreapresencadecupinzeiros. pdf $>$. Accessed: Jan. 19, 2018. 
MAGUIRE, J. D. Speed of Germination-Aid In Selection and Evaluation for Seedling Emergence and Vigor. Crop Science, v.2, n.2, p.176-177, 1962. Available from: $<$ https://dl.sciencesocieties. org/publications/cs/abstracts/2/2/CS0020020176>. Accessed: Feb. 02,2018

MENDONÇA, E. A. F. et al. Seed coating of super sweet corn. (sh2). Revista Brasileira de Sementes, v.29, n.2, p.68-79, 2007. Available from: <http://www.scielo.br/pdf/rbs/v29n2/v29n2a10>. Accessed: Jan. 06, 2018.

NASCIMENTO, W. M. et al. Carrot seeds germination osmotically conditioned and pelleted with ingredients. Horticultura Brasileira, v.27, n.1, p.12-16, 2009. Available from: $<$ http://www. abhorticultura.com.br/biblioteca/arquivos/Download/biblioteca/ HB27_1.pdf\#page=12>. Accessed: Jun. 05, 2018.

PEREIRA, C. E. et al. Seeds storage of pelleted braquiaria and treated with fungicides and inseticides. Ciência Rural, v.41, n.12, p.2060-2065, 2011. Available from: <https://www.redalyc.org/ html/331/33121069004/>. Accessed: Jan. 18, 2018.
SAEG (Sistema para Análises Estatísticas), Versão 9.1: Fundação Arthur Bernardes - UFV - Viçosa, 2007. Available from: <http:// arquivo.ufv.br/saeg/>. Accessed: Feb. 02, 2020.

SANTOS, F. C. et al. Chemical treatmet, coating and seeds storage of Brachiaria brizantha cv. Marandu. Revista Brasileira de Sementes, v.32, n.3, p.69-78, 2010. Available from: $\quad<\mathrm{http}$ //www.scielo.br/scielo.php?script=sci_arttext\&pid $=$ S0101-31222010000300008>. Accessed: Jan. 17, 2018 .

SILVA, F. W. A. et al. Germination Performance of estilosantes Campo Grande (Stylosanthes capitata/macrocephala) Seeds Coated with Different Layers of Inert Material. American Journal of Experimental Agriculture, v.18, n.4, p.1-8, 2017. Available from: $<$ http://www.journalrepository.org/media/journals/JEAI_51/2017/ Nov/Silva1842017JEAI36768.pdf > . Accessed: Jan. 10, 2018.

XAVIER, P. B. et al. Physiological potential of Stylosanthes cv. Campo Grande seeds coated with different materials. Journal of Seed Science, v.37, n.2, p.117-124, 2015. Available from: $<$ http:/www.scielo.br/pdf/jss/2015nahead/2317-1537-jss-23171545v37n2145982.pdf $>$. Accessed: Jan. 09,2018. 